\title{
Hot och våld i vård och omsorg - åtgärdsförslag $i$ arbetsskadeanmälningar 1987, 1997 och 2007
}

\author{
SOFIA WIKMAN
}

Om en arbetstagare skadas, t.ex. på grund av hot och våld, ska arbetsgivaren göra en arbetsskadeanmälan. I anmälan kan förslag till åtgärder som kan förhindra att händelsen sker igen anges. I den här artikeln analyseras de åtgärder som vård-och omsorgspersonal förespråkar från åren 1987, 1997 och 2007.

År 2010 gjordes ca 2500 arbetsskadeanmälningar om hot och våld. En tredjedel av dessa kommer från vård- och omsorgssektorn - en av de mest utsatta yrkesgrupperna (Arbetsmiljöverket 2011). Diskussionerna kring hur man skapar en god arbetsmiljö har sedan den första arbetsmiljölagen instiftades 1905, präglats av att det är arbetstagarna som har kunskap om hur en god arbetsmiljö skapas (Hydén 2004:134). Den officiella statistiken över olycksfall i arbetet, där hot och våld ingår, började publiceras år 1906 och samlas i

Sofia Wikman, fil Dr, Kriminologiska Institutionen, Stockholms universitet informationssystemet om arbetsskador (ISA) vars syfte bland annat är att skapa ett underlag för förebyggande arbetsmiljöarbete (Arbetsmiljöverket 201 la:28). Fokus i den här artikeln ligger på de våldsutsattas åtgärdsförslag (se figur 1).

En fördel med att studera arbetsskadeanmälningar är att det ger en möjlighet att se till hur de utsatta själva ser på åtgärder. Dessutom finns de insamlade över en längre tidsperiod vilket ger möjlighet att se om det skett förändringar över tid. Den här studien fokuserar på tre specifika år 1987, 1997 och 2007. Under 1990-talet minskade bemanningen av personalen inom sjukvård och äldreomsorg i stort sett kontinuerligt 
(SOU 2000:3). Enligt en beräkning av Gustavsson (2004) var det 15 procent färre som tog hand om en lika stor men åldrande befolkning år 2001 jämfört med år 1990. Larsson (2004) menar att den kommunala sektorn under 1990- talet erfor en kraftigt försämrad arbetsmiljö. För äldreomsorgens vårdbiträden har arbetsmiljön förvärrats jämfört med ingången till 1990-talet (Gustafsson \& Szebehely 2005). Sedan början av 1990-talet har man i Statistiska centralbyråns undersökningar om levnadsförhållanden (ULF) sett en ökning av utsatthet för yrkesrelaterat våld inom de kvinnodominerade välfärdssektorerna vård, skola och omsorg (Estrada, Nilsson \& Wikman 2007; Wikman 2012). Ökningen förklaras med en ökad anmälningsbenägenhet och en förändrad arbetsmiljö och sker medan andra utsatta näringsgrenar som handel, polis och övervakning inte visar motsvarande ökningar (Estrada, Nilsson, Jerre \& Wikman 2010).

Parallellt med att våldet mot vårdanställda ökar och ges mer uppmärksamhet sker också vissa förändringar i synsättet på hur våldet ska bemötas. En studie över förslag till åtgärder mot våld $i$ arbetslivet i fackliga tidningar visar att det blir vanligare att den vårdanställde framställs som ett brottsoffer vars upprättelse kräver insatser från rättsväsendet snarare än förebyggande och rehabiliterande insatser från arbetsgivaren (Wikman 2011). Studien visar också en utveckling mot förrättsligande och ansvarsgörande. Frågan är om detta återspeglas när de våldsutsatta själva föreslår åtgärder? För att kunna proble-

\section{Figur I.}

Detalj av FK 9348, Försäkringskassans blankett för anmälan av personskada och arbetsskada (Anmälan ska ske till försäkringskassan om den kan antas medföra rätt till ersättning, enligt socialförsäkringsbalken 42 kap. 7-9 \$\$ samt föreskriften förordningen om arbetsskadeförsäkring och statligt personskadeskydd(SFS 1977:1166) 2\$).

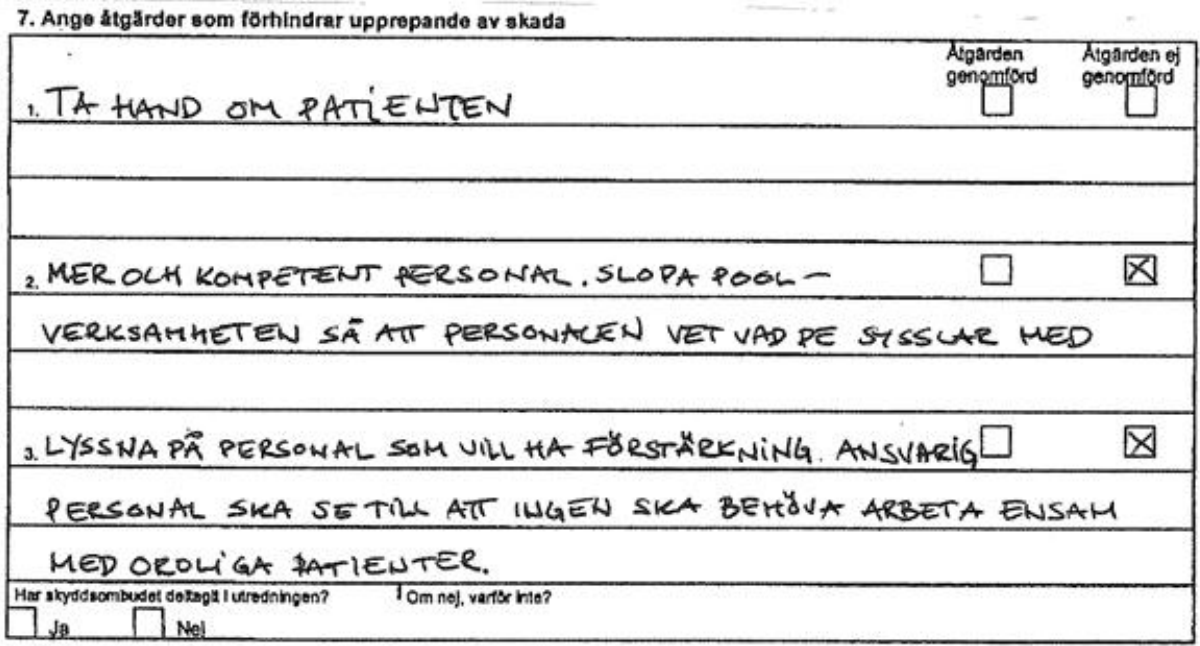


matisera frågan om handlingsramar och åtgärder förändrats över tid är det nödvändigt att ta hänsyn till om våldet sker i nya situationer eller om våldet har förändrats till sin karaktär, t.ex. blivit grövre. Syftet är att analysera och kategorisera de åtgärder våldsutsatt personal själv föreslår och diskutera förändringar över tid. Studiens frågeställningar är:

- Hur har det våld som anmäls förändrats över tid? Sker våldet i nya situationer och har våldet ändrat karaktär?

- Har synen på våldsverkaren förändrats?

- Vilka åtgärder föreslår de våldsutsatta i arbetsskadeanmälningarna? Har åtgärdsförslagen förändrats över tid?

Närmast kommer en genomgång av forskning om åtgärder mot våld $i$ arbetslivet följt av studiens teoretiska utgångspunkter och en kort presentation av de tolkningsramar som används som analysverktyg. Resultatet presenteras i två steg, dels i form av citat från anmälningarnas fritexter, dels med en kvantitativ översikt som visar åtgärdernas förekomst samt utveckling. Avslutningsvis följer en sammanfattande diskussion.

\section{Forskning om åtgärder mot våld $\mathrm{i}$ arbetslivet}

En betydande del av forskningen om våld i arbetslivet har ägnats åt frågor som har med våldets omfattning att göra samt vilka risksituationerna är. I en litteraturstudie (Wikman m.fl. 2010) påvisas att några situationer är kända för att kunna öka oro och aggression. Det är negativa besked, nekad tillgång till service, köbildning, stressad personal samt "allmän rörighet". En stor del av det våld som utspelar sig inom vården sker i samband med aktiviteter som tvättning, på- eller avklädning, matning och liknande (Larsson m.fl. 2011). Fysiska omständigheter som dålig luft, belysning och obekväm temperatur kan också skapa frustration som i sin tur kan leda till aggression och våld (Wikman m.fl. 2010).

Det finns även en motsättning mellan behovet av närhet till patienterna, ett snabbt omhändertagande och kravet på försiktighet för personalen. På akutmottagningen ska personalen hjälpa den behövande så snabbt som möjligt samtidigt som farliga och vassa föremål som t.ex. sprutor måste upptäckas. Hög arbetsbelastning kan öka risken så att man inte hinner med dessa försiktighetsåtgärder. Nedskärningar i form av uppsägningar och/eller en minskad personaltäthet per klient/patient har också påvisats som risksituation. Att ha låg kontroll, i bemärkelsen små möjligheter att påverka sin arbetssituation, bristande kunskap och kort erfarenhet är också associerat med en ökad risk att utsättas för våld på arbetsplatsen (Wikman m.fl. 2010).

Flera forskare har konstaterat att kunskapen om åtgärder mot våld $i$ arbetslivet är mer begränsad (Menckel \& Hultin 2004; Paterson m.fl. 2009; Bowie 2011). Ett problem som har identifierats i en kunskapsöversikt om våld $i$ arbetslivet är att det är få åtgärder mot våld $i$ arbetslivet som utvärderats och har empiriskt stöd (Wikman m.fl. 2010). Detta gäller både åtgärder i form av direkta reaktioner på våldet och långsiktiga brottspreventiva strategier (Braverman 2002; Chappell \& Di Martino 2006). 
Vikten av ett preventivt fokus på våld som undviker reaktiv kontroll betonas ofta och hänvisningar till komplexiteten i de orsaker som kan leda till våld, och därmed också hur det skall åtgärdas, är också återkommande. Sammantaget har faktorer som har med arbetets organisation att göra stor betydelse för att förstå varför våld uppstår (Björkdahl 2010; Bowie 2011; Jones 2011 m.fl.).

I en utvärdering av stöd till brottsoffer på arbetsplatser framkommer att stöd från kollegor och avsatt tid att tala om det som hänt på arbetsplatsen upplevs som meningsfullt av den utsatta personalen (Carlsson \& Wennerström 2010). I en riksrepresentativ intervjustudie, från början av 1990-talet, med 400 sjukvårdsanställda anger 45 procent av de anställda att arbetsgivarna borde göra mer för att hantera de "aggressiva" patienterna (Åkerström 1993). De åtgärder som främst efterfrågas är psykologisk eller medicinsk utbildning för att förstå patienternas aggressivitet. I övrigt är det stora skillnader mellan åtgärder som efterfrågas på olika arbetsplatser. Personal på akutmottagningar efterfrågar såväl tekniska lösningar som utbildning medan personalen på vårdcentraler, mentalsjukhus och sjukhem i varierande grad efterfrågar utbildningar i greppteknik och självförsvar (Åkerström 1993:46).

\section{Vad fyller en arbetsskadeanmälan för funktion?}

I arbetsskadeanmälan finns en särskild ruta där den skadade uppmanas att skriva ner förslag på åtgärder som kan förhindra att skadan sker igen. Pettersson (2005) som undersökt arbetsskadeanmälningar på grund av utbrändhet, menar att även om vad som bedöms som en arbetsskada regleras i lagstiftningen, är arbetsskador socialt konstruerade. Anmälningarna framstår, enligt Pettersson, som ett sätt att "säga stopp" och kan ses som en vittnesbörd av missförhållanden på arbetsplatsen. Hon visar exempel på anmälare som skriver att de gör en arbetsskadeanmälan för att andra ska få veta hur det står till på arbetsplatsen och att det kan leda till en förändring som inte bara gäller den egna arbetsplatsen utan hela samhällssektorer (Pettersson 2005).

Åkerström (1997:130) har visat att en arbetsskadeanmälan kan betraktas som en plikthandling inom vissa vårdkulturer. Att arbetsskadeanmäla kan vara ett sätt att synliggöra och dokumentera arbetsbelastningen. Pettersson (2005) lyfter fram att anmälarnas argumentation visar på förväntningar på ett ansvarstagande som går utöver den ekonomiska och försäkringsmässiga relationen där staten förväntas ta ansvar för arbetsmiljön. I arbetsskadeanmälningarna ger anmälarna uttryck för en vision av arbetsskadeförsäkringen som innefattar en tillit till statens och den politiska styrningens möjligheter.

\section{Teoretisk utgångspunkt}

Det finns ett antal föreställningar, ofta outtalade, som utgör förutsättningar för att en åtgärd ska framstå som rationell. På så sätt impliceras brottslighetens orsaker och vad som är möjligt att påverka (Giertsen 1994:299; Sahlin 2000:83). Till exempel 
präglas olika akademiska discipliner av olika åtgärdstraditioner beroende på vilka studieobjekten är. Psykologer ägnar sig i huvudsak åt individers beteenden medan sociologer forskar om gruppers agerande, vilket också styr vilken åtgärd som finns "till hands" (Paterson m.fl. 2009). Att förebygga problem likställs ofta med att motverka deras uppkomst (Sahlin 2000:24). Sahlin hävdar däremot att det råder ett ömsesidigt beroende och samtidigt ett relativt oberoende mellan åtgärder och problem, vilket innebär att preventiva insatser har andra funktioner än deras offentliga motivering anger, samtidigt som åtgärderna kan påverka föreställningar om ett problem och dess orsaker (Sahlin 2000: 80).

Denna dubbla funktion framkommer i en undersökning av arbetsskadeanmälningar av Åkerström (1997) där hon undersöker lokala praktiker, vilket innebär olika förhållningssätt till att tolerera, hantera och anmäla våld på olika arbetsplatser. Åkerström visar att det var vanligare att arbetsskadeanmäla inom mentalvården än i äldrevården, akutvården och öppenvården. En förklaring som framfördes var att mentalskötarnas skador var värre. En annan förklaring var att personalen ville påvisa en hög arbetsbelastning. Enligt Åkerström (1997) kan arbetsskadeanmälningar ha både en manifest funktion, dvs. att erhålla ekonomisk ersättning men också en latent funktion, dvs. att användas i retoriskt syfte t.ex. för att dokumentera vårdtyngd.

Ett annat av Åkerströms (2000) resultat är att gränsdragningsproblematiken kring vilka händelser som faller utanför respektive innanför begreppet våld i vården snarare involverar kategoriseringar av människor än händelser. I den här studien antas, att det som har betydelse för vilken åtgärd som anges, är var och $\mathrm{i}$ vilken situation våldet sker samt våldets karaktär. Utöver detta samverkar allt detta även med synen på våldsverkaren som antingen rationell "skurk" och därmed mottaglig för straff som innebär avskräckning eller som "stackare" och därmed immun för påverkan i form av straff, utan snarare i behov av vård eller omsorg. Om brottsligheten kan betraktas som ett symtom på en sjukdom försvinner incitamentet att straffa genom att brottets moraliska dimension att medvetet skada någon annan tonas ner, till skillnad från om en våldsverkare som är en rationell aktör och ensam ansvarig som kan ta konsekvenserna av sitt handlande $i$ form av fängelse eller annat straff (Tham 2002). Begreppsparet stackare och skurk används i den här studien för att motsvara det klassiska temat med vård eller straff som bygger på två sinsemellan olika och oförenliga system, medicinen och juridiken. Dikotomin används för att fånga upp skillnaden mellan två stereotyper som kan betraktas både som ett uttryck för och som ett argument för en viss policy. Som sådan är inte dikotomin absolut utan ett element i konstruktionen av sociala problem (jfr Sahlin 1994).

\section{Tolkningsramar}

Framingbegreppet ${ }^{1}$ användes först av Goffman (1974), och används ofta för att

1 I den här studien används även det svenska ordet tolkningsram som synonym till "frame". 
beskriva sociala rörelsers "policymaking" (Paterson m.fl. 2010). "Framing" är en dynamisk process av formandet av kollektiva handlingsramar som människor skapar för att föra fram sina åsikter (Benford \& Snow 2000). Under mina studier av tidigare forskning har jag till exempel gjort aktiva val och tolkat det som framställs och "ramas in", som mer relevant än andra budskap. Tentativa tolkningsförslag jämförs därefter med specifika exempel. När ramarna återkommer får de en självklar status som ett slags "genre". Ramarna representerar inriktningar och metoder som implicit och explicit utgör perspektiv på hur våldsproblemet definieras och förutsätter en viss syn på våldets orsaker. Teorin betonar en dynamisk process som jag menar passar för att studera konstruktionen av synen av brottslingen och de åtgärder som följer av denna syn. Detta påminner om det som andra har kallat gränssättningsarbete (se Gieryn 1983, 1995 och Åkerström 2000). Till skillnad från gränssättningsarbete som visar vilka handlingar eller händelser som faller innanför begreppet våld involverar ramarna i denna studie synen på de människor som begår våldshandlingarna. Det som undersökts är vem gränsen gäller snarare än var gränsen går. I följande avsnitt återkommer jag till hur tolkningsramarna metodologiskt appliceras på materialet.

\section{Data och metod}

\section{Data}

För att kunna beskriva förändring över tid, valdes anmälningar från tre år: 1987, 1997 och 2007. Urvalsramen består av samtliga anmälningar från de yrkesgrupper inom vård och omsorg som är mest utsatta för hot och våld ${ }^{2}$ enligt arbetsskadestatistiken (Wikman 2012). Från år 1987 valdes samtliga anmälningar och från år 1997 valdes var tredje anmälan och år 2007 valdes varannan anmälan, detta gjordes för att få ett tillräckligt stort antal från varje år för att möjliggöra nedbrytningar.

Det totala antalet arbetsskadeanmälningar varierar stort mellan de olika åren (se tabell 1) vilket har flera olika förklaringar. Statistiken har publicerats med i huvudsak samma innehåll och metodik sedan 1979, men systemen åren 19801993, 1994-2002 och 2003-2008 är inte direkt jämförbara med varandra. Till exempel har indelningen i näringsgrenar och yrkesgrupper förändrats över tid. 1992 infördes en sjuklöneperiod på 14 dagar under vilken arbetsgivaren betalar lön vid sjukdom. Förändringen har sannolikt inneburit att arbetsskador med kort sjukskrivningstid inte rapporteras i samma utsträckning som tidigare. 1993 infördes en karensdag i sjukförsäkringen vilket ytterligare kan ha minskat anmälningsbenägenheten för kortare sjukskrivningar. Antalet lindriga händelser antas vara högre år 1997 än de andra åren eftersom det då registrerades arbetsolyckor utan frånvaro, t.ex. tandskador, hörselnedsättning och psykisk reaktion (vid hot, rån etc.) (Nordin 2000).

2 Ambulanssjuksköterska och vårdare, boendestödjare, barn- och ungdomsvårdare, habiliteringsassistent, hemvårdare, personlig assistent, mentalskötare, sjuksköterskor, sjukvårdsbiträde och undersköterska. 
För att motverka tendensen att vissa år kan innehålla fler anmälningar av det "lindrigare våldet", eftersom man kan anta att det är den typ av våld som påverkas mest av förändringar som avser anmälningsrutiner etc., kommer de analyser som tar fasta på förändring över tid att baseras på det grövre och allvarligare våldet.

Anmälningarna rör handlingar som kan vara aktuella för straff ${ }^{3}$. Allt annat har sorterats bort. I ett fåtal fall ${ }^{4}$ t.ex. när personen inte kommit tillbaka till arbetet, kan skyddsombudet eller annan representant för arbetsplatsen ha fyllt i anmälan annars är det den skadade själv som undertecknat och därmed kan antas ha fyllt i anmälan.

Materialets fördelar består i att det kan ge oss kunskap om vilka åtgärder som föreslås över tid av hot och våldsutsatt vårdoch omsorgspersonal i kombination med en djupare förståelse av i vilket sammanhang våldet sker. En nackdel är att det inte finns

3 Hot, våld och sexuella handlingar definieras enligt 3 kap 5 § och 6 § brottsbalken och de så kallade vaillandebrotten i 3 kap 7 § brottsbalken samt arbetsmiljölagen (1977:1160) 8 kap.

4 Detta är sällsynt och gäller högst någon enstaka procent av anmälningarna. möjligheter att ställa följdfrågor, som vid intervjuer, och att informationen ibland är knapphändig.

\section{Operationaliseringar}

\section{Åtgärder}

Flera åtgärder ${ }^{5}$ kan anges på blanketten. Dessa kodas enskilt. Psykosocial arbetsmiljö avser förändringar av personalstyrka, köer, ensamarbete, öppettider och nattarbete. Mer resurser och handledning och krishantering är åtgärder som är en del av psykosocial arbetsmiljö men dessa kodas även separat. I åtgärden medicinering av patient ligger fokus på att anpassa patienten till miljön genom ökad medicin/annan diagnos, vårdplanering eller vårdform. Informationsarbete avser utbildningsinsatser på gruppnivå, kartläggning av problemet, tillsättandet av arbetsgrupper, uppdatering av rutiner.

Fysisk arbetsmiljö inriktad på arbetsruti-

5 För en översikt om åtgärder och riskfaktorer när det gäller våld i arbetslivet (se Wikman m.fl. 2010)

\section{Tabell I}

Antal arbetsskadeanmälningar efter olika steg i urvalsprocessen (ISA 1987, 1997 och 2007).

\begin{tabular}{lcccc}
\hline Vårdpersonal & $\mathbf{1 9 8 7}$ & $\mathbf{1 9 9 7}$ & $\mathbf{2 0 0 7}$ & Samtliga \\
\hline Totalt antal anmälningar & 587 & 1579 & 779 & 2945 \\
\hline Urval & 587 & 526 & 389 & 1502 \\
\hline Efter rensning av icke relevanta fall & 531 & 506 & 368 & 1405 \\
\hline Grövre och allvarligt våld & 423 & 273 & 231 & 927 \\
\hline Anmälningar av grövre och allvarligt våld där åtgärder föreslås & 128 & 132 & 144 & 404 \\
\hline
\end{tabular}

Sofia Wikman: Hot och våld i vård och omsorg - åtgärdsförslag... 
ner/moment $i$ arbetet innebär anpassning av lokalen efter verksamheten, besöksrum för patientomhändertagande, tekniska lösningar, avskiljning av patient och inlåsning. Greppteknik kodas som självförsvarsträning.

Fysisk arbetsmiljö inriktad på säkerhet kan betyda skottsäkert glas, larm, reservutgångar, kontanthanteringsrutiner och övervakningskameror kopplade till personal. I aktiv övervakning är övervakningskamerorna istället kopplade till väktare eller polis. Poliser/polisanmälan betyder mer polisnärvaro i samhället och att fler händelser ska polisanmälas.

\section{Risksituationer}

Endast den situation som bäst motsvarar händelseförloppet eller framhålls tydligast kodas. De åtta risksituationerna består av psykisk ohälsa, tillsägelse/negativt beslut, intim situation, arbetsrelaterad stress, matsituation, demens, kontroll över obehöriga och kontanter.

\section{Våldets karaktär}

Våldets karaktär delas in i tre nivåer, lindrigt, grövre och allvarligt våld. Lindrigt våld avser våld som inte lett till synliga märken, knuffar, enstaka knytnävslag eller sparkar som inte riktats mot ansiktet. Som grövre våld kodas händelser som lett till synliga märken, serier av knytnävslag eller sparkar mot ansiktet. Allvarligt våld innebär våld som enligt anmälan krävt läkarbesök (jfr Brå 2009:6). Kodningen utgår från det som uttrycks explicit.

\section{Vård-och omsorgssektorer}

Det kan vara svårt att veta från vilken vårdoch omsorgssektor en anmälan härrör. I tveksamma fall har jag konsulterat två personer med erfarenhet från akut-, primäroch öppenvård samt socialtjänst. Två personer har kodat samma 80 anmälningar för att kontrollera interkodarreliabiliteten. Ingen variabel fick lägre överensstämmelse än 85 procent.

\section{Metoder}

För att överblicka förekomsten av åtgärderna används kvantitativ innehållsanalys vars styrka är att ge underlag för jämförelse (Bergström \& Boréus 2000). Här räknas åtgärder som kodats i ett kodschema som arbetats fram i samband med en kunskapsöversikt ${ }^{6}$, baserad på 182 svenska vetenskapliga publikationer om våld i arbetslivet åren 1975-2010 (Wikman m.fl. 2010).

Tolkningsramarna syftar till att synliggöra återkommande teman, begrepp och föreställningar i materialet. Dessa kan sedan relateras till varandra, till tidigare forskning och teoretiska ansatser samt organiseras och förstås som ramar över kollektiva handlingar. Alltså prövar jag om åtgärderna kan kodas i enlighet med det

6 Tidigare forskning består av publikationer som genererats genom träffar på sökorden violent, violence, workplace, work, safety crimes, corporate crime samt organizational crime eller dess svenska motsvarigheter i Libris, Criminal Justice Abstracts (CJA), Sociological Abstracts, JSTOR, Artikelsök, Bibliography of Nordic Criminology (BNC) och DIVA. 
förslaget. Ramarna har konstruerats i samband med kodningen av materialet och forskningsgenomgången. Den återkommande pendlingen mellan tolkningsförslag och prövning gör att den här studien både är induktiv och deduktiv och ramarna är således både ett analysinstrument och ett resultat. ${ }^{7}$

7 Till exempel anger en kunskapsöversikt om säkerhetskultur (EU-OSHA 2011) att det europeiska arbetsmiljöorganet European Agency for Safety and Health at Work fäster stor tilltro till forskning om psykosocial arbetsmiljö och organisatorisk utformning som en framkomlig väg för att förena forskning och praktik i det förebyggande arbetet mot komplexa arbetsmiljöproblem.

\section{Det förebyggande arbetets tolkningsramar}

I tablå 1 sammanfattas resultatet i form av de åtgärder som representeras i arbetsskadeanmälningarna. En indelning har gjorts i tre tolkningsramar: normaliseringsramen, kontrollramen och avvikelseramen. De två yttersta ramarna, normalisering och avvi kelse skiljer sig i synen på våldsverkaren. I normaltillstånden till vänster är det "normalt" för klienter inom vård och omsorg att ibland tillgripa våld. Till höger ses våldet som en alltför stor avvikelse så att personen måste tas om hand utanför vård- och omsorgsinrättningarna. Den första ramen, normaliseringsramen, syftar till att skapa

\section{Tablå $I$}

Analysschema för tolkningsramar. Teman och åtgärder (Det finns olika förslag till klassifceringar av den befintliga brottspreventionen i litteraturen t.ex. Balvig (1979-80), Christie (1999) och Sahlin (2000). Jag har inspirerats av samtliga men tablå 1 skiljer sig eftersom denna studie utgår från ett viktimologiskt perspektiv, där det är de våldsutsattas åtgärdsförslag som räknas och tolkas).

\begin{tabular}{l|l|l|l|l|l}
\hline \multicolumn{2}{l}{$\begin{array}{l}\text { Normaliseringsram (Våldsver- } \\
\text { karen är en stackare) }\end{array}$} & \multicolumn{2}{l}{$\begin{array}{l}\text { Kontrollram (Våldsverkaren är } \\
\text { potentiellt både stackare och } \\
\text { skurk) }\end{array}$} & $\begin{array}{l}\text { Avvikelseram (Våldsverkaren } \\
\text { är en skurk) }\end{array}$ \\
\hline Tema & Åtgärd & Tema & Åtgärd & Tema & Åtgärd \\
\hline $\begin{array}{l}\text { Psykosocial } \\
\text { arbetsmiljö }\end{array}$ & $\begin{array}{l}\text { Resurser (tid, } \\
\text { personal och } \\
\text { utbildning) }\end{array}$ & Exkludering & $\begin{array}{l}\text { Diagnos, medici- } \\
\text { nering, inlåsning }\end{array}$ & $\begin{array}{l}\text { Individualisering } \\
\text { av ansvar }\end{array}$ & $\begin{array}{l}\text { Polisanmälan, } \\
\text { böter }\end{array}$ \\
\hline $\begin{array}{l}\text { Organisatorisk } \\
\text { utformning }\end{array}$ & $\begin{array}{l}\text { Rutiner, samtal } \\
\text { med handledare } \\
\text { eller kollegor }\end{array}$ & $\begin{array}{l}\text { Fysiska rutiner } \\
\text { och lokalens } \\
\text { beskaffenhet }\end{array}$ & $\begin{array}{l}\text { Besöksrum, tek- } \\
\text { niska hjälpmedel, } \\
\text { bältesläggning }\end{array}$ & Förrättsligande & Kriminaliseringar \\
\hline & $\begin{array}{l}\text { Fysisk arbets- } \\
\text { miljö inriktad på } \\
\text { säkerhet }\end{array}$ & $\begin{array}{l}\text { Skottsäkert glas, } \\
\text { lås, reception, } \\
\text { larm, nödutgångar. }\end{array}$ & Självförsvar* & Greppteknik etc. \\
\hline
\end{tabular}

\footnotetext{
* Självförsvarsträning är den åtgärd som varit svårast att placera eftersom den kan användas både proaktivt och reaktivt. Jag anser att den passar bättre in bland de åtgärder som samspelar med synen på individen som ansvarig. Dessutom implicerar ett försvar att en våldsam situation redan har eskalerat vilken är en skillnad från åtgärder inom den mer förebyggande normaliseringen.
}

Sofia Wikman: Hot och våld i vård och omsorg - åtgärdsförslag... 
förutsättningar för att ta hand om klienternas och vårdtagarnas beteende, dvs. de är indirekta och inriktade på strukturer. Avvikelseramen innebär en inblandning av polis och åklagarmyndigheter med lagstiftning och rättsväsendet som "brottspreventiva" instrument.

Kontrollramen representerar ett mellanläge som fungerar som en kontrollstation där våldsverkaren kan exkluderas från det egna territoriet eller ansvarsområdet genom att antingen i ett tidigt skede nekas tillträde till verksamheten genom övervakning eller att i ett senare skede sjukdomsförklara patienten så att den inte längre passar in i verksamhetsbeskrivningen eller "avväpna/lugna" patienten genom medicinering.

Redovisningen av ramarna sker härnäst i form av citat från anmälningarnas fritexter. Citaten ligger så nära den ursprungliga texten som möjligt efter hänsynstagande till att de inblandade personerna inte ska kunna identifieras. Av samma skäl anges inte heller årtal. Texterna har ytterligare bearbetats med avseende på läsbarhet, förkortningar har skrivits ut och stavfel korrigerats. I de fall ord eller meningar inte tagits med, visas det med [...]. Det nummer som står inom parentes anger anmälans löpnummer. Exempel från normalramen redovisas först, därefter kontrollramen och sist avvikelseramen. I de utdrag från anmälningarna som redovisas i den följande exemplifieringen förekommer både förslag, beskrivningar av vidtagna åtgärder samt kritik mot att tidigare förslag inte genomförts. Placeringarna i ramar bör därför ses som exempel då citaten ofta innehåller fler åtgärder och följaktligen kan passa in $\mathrm{i}$ flera av ramarna. Förfarandet motiveras av att det underlättar exemplifieringen ${ }^{8}$ av de åtgärder och de sammanhang de förekommer i.

\section{Normaliseringsramen}

\section{Psykosocial arbetsmiljö}

I normaliseringsramen är åtgärder som syftar till att förändra den psykosociala arbetsmiljön centrala. Åsikten att våld i arbetslivet inte bör åtgärdas genom att klandra den enskilde individen, gärningspersonen eller personalen är förhärskande (Braverman 2002; Paterson m.fl. 2009). Våld bör istället ses som ett symptom på ett system med en ickefungerande verksamhetsstruktur. De psykosociala åtgärder som efterfrågas är ofta handledning, information och mer resurser.

Vårdare, gruppboende för psykiskt handikappade (938)

Jag väcktes av nattvakten. Hon hade problem med en boende som fätt tag i en förskärare. Att ensam stå inför en kniv och känna ansvar för de övriga sju personerna som bor här och tillika sitta i telefon och bli "bollad"

8 I den kvantitativa analysen som följer är avsikten inte längre att exemplifiera utan att beskriva och analysera åtgärdernas förekomst vilket kräver en mer strikt hantering av arbetsskadeanmälningar och det som uttrycks på åtgärdsraden för att förhindra att skadan sker igen. Varje åtgärd kodas därför separat och till skillnad från denna exemplifiering är det endast möjligt att placera ett åtgärdsförslag i en ram. 
runt är ingen mänsklig arbetssituation. Att inte få hjälp genast med maximalt ett telefonsamtal var jättefrustrerande. [...] Då jag gick hem kändes det som jag inte visste om jag skulle skratta eller gräta. Jag kände mig enormt lurad över att ingen informerat om hans aggressivitet och att han kan ta till tillhyggen, tänkte mycket på om lönen var värt riskerna.

Åtgärd: Låste in knivar och saxar. Samtal med överläkare. Allt skall fungera vid akuta situationer, t.ex. handräckningsorder till polis. Informera de personer som rapporterar en ny boende hur viktigt det är att vi får veta hur våldsbenägna nya boende är så att man inte undanhailler information.

Det är inte ovanligt att den här typen av åtgärder föreslås för våld som är grovt, till exempel hot med kniv som i exemplet ovan. Den som anmält våldet uttrycker ilska över att inte ha fätt tillräcklig information om patientens tillstånd, men det verkar också finnas ett behov av att prata av sig om känslan av otillräcklighet och frustration över arbetets villkor. Behov av stöd från kollegor och avsatt tid att tala om det som hänt på arbetsplatsen förefaller upplevas som meningsfullt av den utsatta personalen.

\section{Merresurser}

Mentalskötare, avdelning på sjukhus (854) Vi stod på toaletten när patienten vred loss ett metallstångföremål från väggen och hotade att sticka ut mina ögon. Jag fick vrida föremålet ur handen på patienten och skadade handen. Fick en spricka i lillfingret.
Åtgärd som förhindrar upprepande av skada: Lyssna på personal som behöver förstärkning. Överläkare vägrade ordinera extrapersonal. Det medförde att vi inte hade någon möjlighet till avlösning. Patientens oro och aggressivitet skulle ha krävt 2 personer. På grund av situationen hade jag inte möjligheter att lämna patientrummet efter att ha blivit skadad.

I exemplet ovan är det uppenbart att det funnits möjligheter att undvika skadan om det funnits ytterligare bemanning. Personalen hade åtminstone kunnat uppsöka vård tidigare. Andra gånger åberopas vårdtyngden som något som kan åtgärdas trots att personalen som i exemplet nedan är tre personer på en patient.

Mentalskötare, avdelning på sjukhus (1000) Bälteslagd patient togs upp för toalettbesök av 3 skötare och blir på nytt lagd $i$ bälte. I samband med detta riktade patienten en explosiv spark med baida benen som träffade $i$ buken och jag slungades bakait med stor kraft.

Åtgärd som förhindrar upprepande av skada: Minskat antal vårdplatser med oförändrad personalbemanning.

\section{Organisatorisk utformning}

Det är inte sällan många instanser som måste samverka: psykiatri, habilitering, primärvård, färdtjänst, goda män och biståndsbedömare. Listan kan göras lång. Det är tydligt att våldet många gånger beror på att stress uppkommit på grund av oro t.ex. över färdtjänst som inte kommer, möte med ny personal som inte fått tillräcklig 
information etc. Citatet nedan visar också att det kan vara svårt för vårdpersonal att veta var de ska få hjälp, både för egen del och för patientens räkning. I exemplet nedan är det en vikarie som är missnöjd med personalens arbetsmiljö:

Vårdare, vårdhem (1108)

Jag bad patienten att sluta slå i ytterdörren. Då sparkade han mig flera gånger på benen och underlivet. Senare kom patienten in till personalrummet och gav mig en örfil. Jag fick blämärken, spräckt läpp, och näsblod. Åtgärd som förhindrar upprepande av skada: Arbetsplatsen lider av personalbrist, kunskapsbrist och brister i den organisatoriska utformningen. Manlig personal behövs. Det enda "vapnet" personalen hade var att ge patienten skuld. Inga arbetsmetoder. Bristande övervakning och tillsyn. Inga möjligheter till självförsvar mot våld. De två andra kvinnorna lyfte ut patienten ur personalrummet och gav honom hot, skäll och skuld, varför? Anställ utbildad personal, utbilda personalen i självförsvar, kräv ändrade arbetsförhållanden. Utbilda er? Kolla NN som inte ger er information, Vem är det som är skyddsombud?

Enligt denna ram kan våldet sammanfattningsvis förstås som en interaktion mellan en individ och ett system som antingen provocerar fram våld eller tillåter att det sker.

\section{Kontrollramen}

\section{Tekniska lösningar}

Situationellt inriktad teknisk brottspreven- tion har visat sig ha betydelse för att förebygga våld. Till exempel har goda kontanthanteringsrutiner samt begränsade öppettider visat sig vara effektiva sätt för att minska utsattheten för hot och våld inom exempelvis handeln (Geijer \& Menckel 2003). Denna typ av lösningar testas alltmer även inom andra branscher. De tekniska lösningar som föreslås $i$ arbetsskadeanmälningarna handlar ofta om större eller bättre anpassade lokaler. Exemplet nedan visar att lokalernas beskaffenhet kan innebära en påfrestning för patienterna och personalen.

Sjukskötare på sjukhus, psykiatrisk avd (95) Närmade mig en uppvarvad och aggressiv patient för att fä honom att lugna ner sig och gå in på sitt rum för samtal. Jag fick ett hårt knytnävslag, över tinning och ögonbryn.

Åtgärd som förhindrar upprepande av skada: Lokalerna som vi arbetare $\mathrm{i}$ är på tok för små. Patienter och personal trängs på för små utrymmen. Våld och hot om våld har ökat $\mathrm{i}$ takt med att beläggningstaket har ökat. Patienten medicinerades i lugnande syfte. Bestående reducering av platsantalet på avdelningen.

Andra tekniska lösningar som föreslås handlar om att kontrollera vilka som kommer in och ut ur verksamheterna, till exempel på akutmottagningen:

Sjuksköterska på akutmottagning (146)

F.d. patient kom till avdelningen och sade att han bar en sprängladdning på sig och hade utlösaren till denna $i$ händerna. Jag befann mig $i$ hans omedelbara närhet under fyra timmar, då polisen lyckades gripa 
honom. Under hela den tiden var jag övertygad om riktigheten $i$ hotet men kunde inte lämna honom pga. den lugnande inverkan jaghade.

Åtgärd som förhindrar upprepande av skada: Besökskontroll - akuten - nattetid

\section{Exkludering}

Att avlägsna våldsamma patienter från den egna verksamheten kan göras genom att definiera dem som för sjuka (för våldsamma) för den egna vårdformen. Ett annat alternativ är att trots att de är sjuka se dem som ansvariga för sina handlingar enligt den så kallade tillräknelighetsprincipen, dvs. principen om ansvarsförmåga och då se till att rättsväsendet tar hand om dem. Svensk rätt har enligt tillräknelighetsprincipen en särställning eftersom allvarligt psykiskt störda lagöverträdare kan dömas till påföljd för brott (med undantag för fängelse, 30:6 Brottsbalken) (Jareborg \& Zila 2007). Medicinering i form av lugnande medel och inlåsning på det egna rummet kan också ses som en typ av exkludering. Både patologisering, dvs. att förklara patientens våldsamhet på grund av hans eller hennes sjukdom i motsats till en reaktion på ett missförhållande och tillräknelighetsprincipen, dvs. att göra den våldsamme patienten juridiskt ansvarig, kan användas för att förflytta patienten från den egna verksamheten.

Vårdbiträde inom hemtjänst (809)

Jag ställde mig vid diskbänken för att lägga upp mat. Då kom NN, endast iklädd en kondom. Han tryckte upp mig mot väggen och skrek "vi ska knulla" flera gånger och utförde kraftiga samlagsrörelser mot min kropp. Jag greps av panik. Jag såg ingen reträttväg och reagerade genom att utdela en örfil. Då släppte NN taget och jag sprang därifrån. NN skrek efter mig "det är säker sex". Jagbehövde hjälp?

Åtgärd som förhindrar upprepande av skada: Ringde min arbetsledare men hon var inte hemma, ringde min chef men hon var heller inte hemma, ringde det ordinarie vårdbiträdet hos NN. Äntligen! Någon att prata med. Jag var helt förtvivlad, mest över att jag utdelat en örfil, men jag behövde även hjälp att reda ut situationen.

Arbetskamraten rådde mig att kontakta distriktssköterskan på Vårdcentralen. Distriktssköterskan visste inte vad man skulle göra utan skulle fråga en kollega och återkomma telefonledes. Efter en stund ringde distriktssköterskan igen och meddelande att jag skulle polisanmäla händelsen. Jag ringde polisens ledningscentral. Fick till svar att detta inte var en polisiär sak eftersom händelsen inte ansågs som tillräckligt "grov". Polisen säger att NN förmodligen haft en hjärnblödning. Jag fick rådet att kontakta läkare och cykla ner till stationen och göra en polisanmälan. Jag ringde distriktssköterskan igen och bad om hjälp att ringa en läkare och fick beskedet att ringa sjukvårdsupplysningen...

I anmälan ovan råder en oklarhet angående vem som har ansvar för klienten. Är det den ordinarie verksamheten, primärvården, akutsjukvården eller kanske till och med polisen? Nedan följer ett exempel på där man vill frånsäga sig ansvaret genom att flytta klienten till annan vårdinstans: 
Personlig assistent, eget boende (5)

Jag står $i$ köket och tittar ut genom fönstret. Hon ställer sig bredvid. När jag lutar mig lite fram för att titta ut blir hon arg, skriker "nej" och slär mig i magen med handen.

Åtgärd som förhindrar upprepande av skada:

19 maj: Omsorgstagaren flyttas till korttidsboende för att boendepersonalen är orolig för hur omsorgstagarens aggression ska bemötas.

21 maj: Omsorgstagaren tillbaka till sin bostad.

22 maj: Planeringsmöte med anhöriga, läkare, sjuksköterska och handläggare. Läkare bedömer att mer medicin ger biverkningar i form av trötthet. Handledning till personalen rekommenderas, bland annat bemötande. Kuratorn handleder i bemötande, förhållningssätt och neurologiska skador.

I citatet bedöms omsorgstagaren först som för sjuk (våldsam) för att vara hemma men friskförklaras två dagar senare och skickas hem igen. Därefter kallas till möte där förslag till ytterligare medicinering ratas till förmån för förslag att det är personalens bemötande som bör förändras, dvs. händelsen slutar i den första ramen, normaliseringsramen. I nästa exempel blir en förståndshandikappad man omhändertagen av polis och förflyttas därmed från normaliseringsramen till avvikelseramen:

Vårdare, gruppbostad för förståndshandikappade (561)

Han ställer sig $i$ dörröppningen, skriker "djävla horor och fittor" och hotar med vaild. Han tar ett par steg in och skickar en stol med djävulsk kraft mot personalen. L fär stolen på sig och hon säckar ihop i soffan. $P$ låser dörren till kontoret. Han vrålar och kastar möbler mot dörren. Skriker att han ska mörda oss och att han ska sticka kniven $i$ L. Tre polisbilar kommer och tar hand om honom.

Åtgärd som förhindrar upprepande av skada: I två års tid har personalen påpekat att boendet inte passar N.N. och att bemanning är för låg (ensamarbete). N.N.s våldsutbrott har ökat i styrka. Personalen har påpekat detta till chefen vid flera tillfällen. Vi har bett om mer personal, larm och en omarbetad handlingsplan för hot och våld. Personalgrupper har vid flera tillfällen bytts ut pga. för stor psykisk belastning och fysiskt våld.

I exemplet nedan är ansvarsfrågan återigen problematisk. Det är dock oklart om anmälaren föreslår att patienten ska vårdas med hjälp av tvångslagstiftning och att detta skulle medföra mindre risk för utåtagerande beteende, eller skulle patienten ha vårdats på annan avdelning med mer och/eller andra resurser? Frågan är också vilken beredskap för våld som finns på en akutmottagning för psykiskt sjuka. Kanske måste man vara lagom sjuk för att söka vård på psykakuten?

Skötare på akutpsykiatrisk avdelning (637) Patienten ringer SOS frän korridoren pa akutpsykiatrisk avdelning. Vardare informerar om att han inte kan fortsätta ringa SOS. Får då ett hårt knytnävsslag $i$ höger ansiktshalva.

Åtgärd som förhindrar upprepande av skada: Rätt vårdform för patienter. Inte låta denna "typ" av patient "gå runt på avdel- 
ningar" utan vidare åtgärder, ex. vård enligt HSL. Dessa patienter vårdas på olika kliniker/avdelningar då ingen vill ta ansvar.

\section{Avvikelseramen}

\section{Förrättsligande och individualiseringavansvar}

Samhällets hållning gentemot kriminalitet i allmänhet påverkar synen på hur det arbetsrelaterade våldet bör förebyggas. En studie av utvecklingen av uppmärksamheten för åtgärder mot våld $i$ arbetslivet i facklig press (Wikman 2011), visar att det allt oftare kommer krav på att våld i arbetslivet ska hanteras externt av rättsväsendet mot individer, från att tidigare hanterats internt på arbetet genom att förändra strukturer.

Att ett politiskt eller etiskt förhållande, eller ett förhållande av annan art, blir rättsligt, eller att en fråga börjar behandlas som en rättslig fråga, kallas förrättsligande (Mathiesen 1985; Brännström 2009). Att en fråga förrättsligas innebär inte att alla börjar behandla frågan som rättslig eller att det är oundvikligt att göra det. Det handlar om att en grupp människor vid en viss tidpunkt och i ett visst sammanhang börjar närma sig frågan utifrån den rättliga diskursen. Förskjutningen behöver inte innebära att en fråga uteslutande behandlas inom ramen för den rättsliga diskursen, utan kan likaväl innebära att den rättsliga diskursen blir mer framträdande på bekostnad av andra diskurser.

Till skillnad från en arbetsskadeanmälan kan en polisanmälan innebära potentiellt negativa konsekvenser för en patient (Åker- ström 1997:128). En arbetsskadeanmälan kan däremot bidra till att förbättra och utveckla verksamheten och vara till skydd för medarbetare och patienter. I en arbetsskadeanmälan nedan, är det en skötare som sitter extravak för en orolig patient som skadats. Hon uppger att skadorna hon fått även föranlett en polisanmälan:

Skötare, avdelning för psykiatri (167)

Patienten blev arg för att hon inte fick medicin. Patienten började sparka och klösas på ben, höft och hand.

Åtgärd som förhindrar upprepande av skada: "att lugna patienten", annan avdelning för aggression skulle passa patienten med högre bemanning. Skadorna är polisanmälda.

I det följande exemplet tas kontakt med polis för att hämta en autistisk flicka som inte vill följa med ut.

Handledare, korttidsboende för barn och ungdomar med autism (410)

Ett av barnen ville inte gå ut. Vi försökte på många sätt. Efter ett tag kände barnet sig pressat och slog till mig $i$ huvudet. Jag slog då även $i$ andra sidan av huvudet $i$ ett skåp. Hon är så arg och våldsam att man ringer polis och barnet körs till sjukhus.

Åtgärd som förhindrar upprepande av skada: En personal ska inte vara ensam med barnet.

Situationen löses genom att man ringer till polis men den åtgärd som föreslås är att personalen inte ska vara ensam med barnet vilket indikerar att polisanmälan i det här fallet kan vara ett sätt att visa på situatio- 
nens allvarlighet för personalen och flickans säkerhet snarare än flickans farlighet.

\section{Självförsvar}

Skötare, behandlingshem inom psykiatri (676)

Efter uppmaning att ta av sig ytterkläderna anföll patienten sin kontaktman. Han slog ner henne till golvet och liggande fick hon ta emot upprepade slag och sparkar som träffade huvudet och stora delar av kroppen. Misshandeln pagick en bra stund innan personalen hann ingripa.

Åtgärd som förhindrar upprepande av skada: Kurs i självförsvar. Överfallslarm.

Tidigare var det vanligt att personalen skulle få träning i självförsvar och grepptekniker för att använda dessa på aggressiva patienter. Ett exempel på en sådan verksamhet är den så kallade Bergenmodellen ${ }^{9}$ som omfattar utbildning, både i bemötande och fysiska ingripanden (Björkdahl 2010). Dessa åtgärder sägs dock vara på väg bort (Bowie 2002; Paterson m.fl. 2009) eftersom de implicerar att det är personalens eget ansvar att hantera problemen. Detta kan fungera som ett skuldbeläggande av de anställda istället för att den utlösande faktorn till att

9 Modellen har prövats och utvärderats i en avhandling med resultatet att antalet reaktiva åtgärder i form av tvångsmedicineringar och bältesläggningar ökade under utvärderingsperioden, vilket (bort)förklaras med att det pågick en omorganisation där två kliniker slogs samman till en och antalet platser för samma upptagningsområde begränsades från 28 till 12 (Björkdahl 2010:29). patienten/klientens aggressivitet utreds. I exemplet nedan framstår händelsen som bagatellartad men åtföljs av åtgärder som är omfattande, vilket möjligen kan tolkas som ett sätt att dokumentera vårdtyngd.

Vårdare, Habilitering av döva och dövblinda (342)

Personal och vårdtagare satt på golvet $i$ social samvaro, vårdtagare ställde sig upp, tappade balansen och klev rakt på min fot. Åtgärd som förhindrar upprepande av skada: Kurser i självskydd och konflikhantering, kontinuerlig uppföljning av behandlingsprogram av behandlingsprogram med handledande psykolog. $\mathrm{ABC}$ utbildning i olycksfall. Fortlöpande teckenspråksundervisning. Konsultation av dövpsykiater.

\section{Åtgärdsförslagens förekomst och utveckling över tid}

Vilken av de ramar som presenterats är vanligast? För att beskriva de situationer i vilka våld inträffat, redovisas deras förekomst och om det har skett förändringar under den undersökta perioden. Därefter visas det anmälda våldets karaktär för att kunna relatera det till de föreslagna åtgärdernas förekomst över tid. Sedan redogörs för om samma åtgärder föreslås inom olika vårdoch omsorgssektorer.

\section{Vilka risksituationer framträder $i$ arbetsskadeanmälningarna?}

Man kan anta att de åtgärder som före- 
slås också hänger ihop med den situation i vilket våldet uppkommit. Utifrån en tolkning av arbetsskadeanmälningarnas fritexter har en risksituation kunnat identifieras i tre av fyra anmälningar. I övriga anmälningar saknas tillräcklig information för att kategorisera det som hänt i sådana termer. Risksituationer enligt arbetsskadeanmälningar är att arbeta med psykisk ohälsa, demens eller neuropsykiatriska funktionshinder. De anmälda våldshändelserna sker vanligen även vid situationer som innebär ökad intimitet, blöjbyte och skötsel av den personliga hygienen samt vid måltider. Enligt anmälningarna uppstår våld och hot ofta vid tillsägelser och vid delgivning av negativa beslut. Stress på grund av arbetsbelastning är också en risksituation som i viss mån beskrivs. Andra risksituationer som framkommer, men dock i mindre grad, är kontroll över obehöriga, alkohol- och drogpåverkan samt värdesakshantering.

Dessa risksituationer är kända sedan tidigare (Menckel \& Hultin 2004; Viitasara 2004; Wikman m.fl. 2010) varför en utförligare redovisning lämnas utanför den här studien. Sammanfattningsvis sker små förändringar av risksituationerna över tid vilket är viktigt att ha med sig när vi senare ska tolka de eventuella förändringar som sker i åtgärderna. En mindre ökning av våld som kommer från patienter inom psykiatrin syns i tabell 1 mellan 1997 och 2007.

\section{Förändring av våldets karaktärövertid}

Tabell 2 visar att allvarlighetsgraden på

\section{Tabell I.}

Risksituationer som identifierats i arbetsskadeanmälningar 1987, 1997 och 2007 (n=927) Procentuell fördelning.

\begin{tabular}{lccc}
\hline Risksituation & $\begin{array}{c}\mathbf{1 9 8 7} \\
(\mathbf{n = 4 2 3 )}\end{array}$ & $\begin{array}{c}\mathbf{1 9 9 7} \\
(\mathbf{n = 2 7 3})\end{array}$ & $\begin{array}{c}\mathbf{2 0 0 7} \\
(\mathbf{n = 2 3} \mathbf{)})\end{array}$ \\
\hline Psykisk ohälsa* $^{*}$ & 26 & 27 & 39 \\
\hline Intim situation** $^{*}$ & 27 & 24 & 16 \\
\hline Tillsägelse/negativa beslut & 20 & 18 & 11 \\
\hline Måltider & 5 & 6 & 9 \\
\hline Stress pga. arbetsbelastning & 1 & 0 & 5 \\
\hline Alkohol eller drogpåverkan & 3 & 1 & 2 \\
\hline Kontroll över obehöriga & 1 & 1 & 1 \\
\hline Kontant- eller värdesakshantering & 1 & 0 & 1 \\
\hline Framgår inte & 16 & 23 & 17 \\
\hline Totalt & 100 & 100 & 100 \\
\hline
\end{tabular}

* Tex. demens, ångest, neuropsykiatriskt funktionshinder.

*** T.ex. blöjbyte, skötsel av hygien. 
det våld som anmäls varierar över tid. Det grova våldet är hela tiden vanligast. Det allvarligaste våldet är näst vanligast år 1987 och det lindrigaste våldet minst vanligt. År 2007 är förhållandet mellan det lindriga och allvarliga våldet det omvända.

På grund av att vissa år kan innehålla mer av det "lindrigaste våldet", kommer nästa analys, som tar fasta på en förändring, att baseras på det grövre och allvarligare våldet (se operationaliseringar).

\section{Vilka åtgärder föreslås $i$ arbetsskadeanmälningarna?}

Vilka åtgärder föreslår de som utsatts för grovt och allvarligt våld för att förhindra att det sker igen? I mer än hälften av arbetsskadeanmälningarna anges ingen åtgärd alls. Andelen som anger en åtgärd ökar dock över tid (1987, $30 \%$, 1997, 48 \% och 2007, $62 \%$ ). Tabell 3 avser de som har uppgett någon åtgärd i sin anmälan och visar hur ofta olika åtgärdsförslag förekommer. Eftersom en anmälan kan innehålla flera åtgärdsförslag blir summan i kolumnerna högre än 100. Det år som har högst summa, dvs. 2007, föreslås alltså flest åtgärder. Det sker ingen tydlig ökning av antalet åtgärder som anges. Majoriteten (59 \%) anger dock enåtgärd.

Normaliseringsramen med sina åtgärder som avser förbättringar av den psykosociala arbetsmiljön är i särklass vanligast. De tre åtgärder som ingår i denna övergripande kategori är handledning, mer resurser samt information. I början av perioden är resurser vanligast medan det i slutet är handledning. Handledning ökar mest av alla åtgärder, från att år 1987 inte anges i mer än vart tionde fall till att år 2007 anges i vart fjärde fall.

Kontrollramen där åtgärder som avser diagnostisering/medicinering återfinns relativt ofta. Tekniska lösningar i form av åtgärder som handlar om att anpassa den fysiska arbetsmiljön efter klienterna, t.ex. anpassa lokalen efter verksamheten och tekniska lösningar, förekommer också i lika hög grad under hela perioden. Avvikelseramen med dess typiska reaktiva åtgärder polisanmälan, övervakning och självförsvar förespråkas mycket sällan av de vårdanställda.

\section{Föreslås samma åtgärderför olika typer av våld?}

Inom vård och omsorg finns det olika klientgrupper och personalen kan därmed för-

Tabell 2.

Våldets grovhet (lindrig, grovt eller allvarligt) andel enligt de arbetsskadeanmälningar där det framgår 1987, 1997 och 2007 (n=1249). Procent.

\begin{tabular}{lccc}
\hline Våldets grovhet & $\mathbf{1 9 8 7}(\mathbf{n}=\mathbf{5 2 2})$ & $\mathbf{1 9 9 7}(\mathbf{n = 3 9 9 )}$ & $\mathbf{2 0 0 7}(\mathbf{n = 3 2 8})$ \\
\hline Lindrigt & 18 & 32 & 29 \\
Grövre & 50 & 47 & 48 \\
Allvarligt & 32 & 22 & 23 \\
\hline
\end{tabular}


väntas ha olika strategier för hur det skall hanteras. Andelen som föreslår psykosociala åtgärder är ökande, både sett till hela materialet och nedbrutet på samtliga typer av våld (lindrigt, grovt och allvarligt) samt olika vård- och omsorgssektorer (t.ex. psykiatrin, äldreomsorgen eller handikappomsorgen).

Tabell 4 visar att normaliseringsramen är dominerande oavsett vilken klientgrupp som avses. Samtidigt uppvisar olika vård- och omsorgssektorer små skillnader i mönster, där den tydligaste är att avvikelseramen föreslås som var femte åtgärd inom beroendevården, jämfört med var tjugonde inom äldrevården.

\section{Diskussion}

Arbetsskadeanmälningarna fångar upp

\section{Tabell 3.}

Fördelning $i$ procent av åtgärdsramar och åtgärder $i$ anmälningar av grovt och allvarligt vaild år 1987, 1997 och 2007. (n=404). Procent.

\begin{tabular}{l|lccc}
\hline Ram & Åtgärder & $\begin{array}{c}\mathbf{1 9 8 7} \\
(\mathbf{n = 1 2 8})\end{array}$ & $\begin{array}{c}\mathbf{1 9 9 7} \\
(\mathbf{n = 1 3 2})\end{array}$ & $\begin{array}{c}\mathbf{2 0 0 7} \\
\mathbf{( n = 1 4 4 )}\end{array}$ \\
\hline Normalisering & Handledning & 53 & 75 & 77 \\
& Mer resurser & 74 & 55 & 46 \\
\multirow{2}{*}{ Kontroll } & Information & 9 & 25 & 24 \\
& Diagnos/medicinering & 38 & 39 & 32 \\
Avvikelse & Fysiska rutiner & 25 & 17 & 23 \\
& Fysisk säkerhet & 19 & 11 & 16 \\
& Självförsvarsträning & 5 & 12 & 9 \\
& Polis/polisanmälan & 0 & 0 & 2 \\
& Aktiv övervakning & 4 & 6 & 2 \\
& Summa (\%) & 161 & 161 & 172 \\
\hline
\end{tabular}

\section{Tabell 4.}

Ramarnas fördelning inom olika vård- och omsorgssektorer. Andelar av åtgärder. (ISA 1987, 1997 och 2007). Procent.

\begin{tabular}{lccccccc}
\hline & Barn & Psykiatri & Beroende & Sjukvård & Äldre & $\begin{array}{c}\text { Funktions- } \\
\text { hinder }\end{array}$ & Total \\
\hline $\begin{array}{l}\text { Normali- } \\
\text { sering }\end{array}$ & 67 & 47 & 42 & 52 & 60 & 63 & 56 \\
\hline Kontroll & 21 & 44 & 39 & 39 & 36 & 27 & 35 \\
Avvikelse & 12 & 9 & 19 & 9 & 4 & 9 & 9 \\
\hline Totalt (n) & 100 & 100 & 100 & 100 & 100 & 100 & 100 \\
& $(42)$ & $(231)$ & $(31)$ & $(95)$ & $(154)$ & $(219)$ & $(852)$ \\
\hline
\end{tabular}


delar av det grövsta våldet som vård- och omsorgspersonalen utsätts för i arbetet. Om tendensen att samhället präglas av förrättsligande samt att ett individuellt ansvarsgörande (Brännström 2010, Rasmussen 2010 och Wikman 2012) fått genomslag för hur vårdpersonal resonerar kring hur hot och våld på deras arbetsplatser ska åtgärdas, borde det synas här, eftersom det framförallt är för det grövsta våldet som det krävs insatser av externa aktörer såsom polis och rättsväsende. Men något sådant går inte att se i materialet.

De våldsutsatta inom vård och omsorg föreslår oftast åtgärder inom normaliseringsramen för att förbättra den psykosociala arbetsmiljön. De anställda ser främst att våldsproblemet, oavsett vilken risksituation som föregått våldet, löses internt på arbetsplatsen, t.ex. genom att sitta ner och prata igenom vad som har hänt med de andra i personalen i form av handledning eller debriefing. Resurser i form av tid och personal för att utföra arbetet efterfrågas gång på gång. Inom kontrollramen "löses" ibland våldsproblematiken genom att ansvaret kan förläggas någon annanstans, antingen genom att våldsverkaren förklaras för sjuk för att vårdas, eller också som ansvarig för sitt handlande trots att dessa patienter och klienter många gånger $\mathrm{i}$ sitt agerande bara handlar i enlighet med sin diagnos eller sitt sjukdomstillstånd. Åtgärder inom avvikelseramen som innehåller repressiva åtgärder från polis och rättsväsende är ovanligt.

Att de våldsutsatta inte skuldbelägger enskilda individer är ett resultat som är i linje med ett flertal andra studier (Jones m.fl. 2011). Det är inte några få "skurkar" som stör verksamheten utan våldet uppfattas uppkomma på grund av att människor som arbetar inom vissa verksamheter, oavsett individuella karakteristika som social klass, ålder eller kön, löper högre risk att konfronteras med klienterna på grund av arbetets "natur". Att polis och kontrollapparaten inte tillgrips handlar sannolikt om att vårdapparaten är just en vårdapparat: om personalen tillgriper dessa blir patienter inte en "patient" och de själva inte "vårdande" (jfr Åkerström 2002).

En skillnad mot Åkerströms (1993) studie av hot och våld mot sjukvårdsanställda, där grepptekniker och självförsvar efterfrågades av cirka en fjärdedel av de anställda, är att sådana åtgärder efterfrågas mycket sällan i den här studien. Denna skillnad kan bero på att den här studien handlar om de som utsatts för grovt våld till skillnad från Åkerströms som vänder sig till ett urval av sjukvårdsanställda, inte enstaka våldsutsatta samt att självförsvarsträningen var ett förutbestämt svarsalternativ ${ }^{10}$ i Åkerströms undersökning.

En invändning mot att använda personalens åtgärdsförslag i det förebyggande arbetet är att personalen kanske efterfrågar vissa åtgärder för att det är bekvämt med mer resurser. Här har det dock skett förändringar. Förr var det främst resurser som efterfrågades, idag är det oftare handledning som önskas (se Carlsson \& Wenner-

10 Bland de svarsalternativ som förekom saknades ett tydligt fokus på psykosociala åtgärder. De alternativ som angavs var överfallslarm, utbildning för att förstå patienter, utbildning i greppteknik och kurs i självförsvar (Åkerström 1993: appendix s. 9) 
ström 2010). Om det är mer tid för intern handledning som efterfrågas, eller om det är mer frekvent eller annorlunda handledning som efterfrågas, är inte möjligt att avläsa ur arbetsskadeanmälningarna. Dessa åtgärder implicerar dock att våldsverkaren ses som ett offer för omständigheter denne inte rår över.

Det anmärkningsvärda är att ett förrättsligande och ansvarsgörande som präglar utvecklingen av kriminalpolitiken i stort och uppmärksamheten i den debatt som framträder i fackpressen, inte kommer till uttryck hos dem som arbetar i organisationen, eller ens bland dem som blivit utsatta för våld och hot i arbetet. Resultatet kan tolkas som att det kan finnas ett motstånd mot att bejaka åtgärdsförslag inom organisationen, hos ansvariga för verksamheten och chefer som har befogenhet att imple- mentera åtgärder. Detta förfarande förekommer inte bara inom vården utan även i andra branscher där olyckor/avvikelser förekommer (Lundberg m.fl. 2011) och kan bero på att de åtgärder som finns till hands påverkar problemförståelsen. Den våldsutsatta analyserar situationen utifrån en annan kunskapsbas än dem som befinner sig längre bort från händelseförloppet och i efterhand ska bilda sig en uppfattning.

Att det finns samband mellan känslan av låg kontroll, höga krav, stress och bristande socialt stöd har visats i ett flertal studier om arbetsplatsvåld och psykosocial arbetsmiljö (Wikman m.fl. 2010). En fara med att vård- och omsorgspersonalens åtgärder inte hörsammas är att det kan leda till en känsla av ytterligare högre krav och mindre kontroll, som kan leda till mer stress och därigenom även mer våld.

\section{Referenser}

Arbetsmiljöverket (2011). Arbetsmiljöstatistik. Arbetsskador 2010. Rapport 2011:1. Stockholm: Arbetsmiljöverket.

Brå (2009). Grövre våld i skolan. Rapport 2009:6. Stockholm: Brottsförebyggande rådet.

Balvig (1979-80). Samfundsplanlægning og kriminalitetsforebyggene tiltag. Nordisk Tidsskrift for Kriminalvidenskab. ss. 96-111.

Benford, R. D. \& Snow, D. A. (2000) "Framing Processes and Social Movements: An overview and Assessment". Annual Review of Sociology. ss. 611-639.

Bergström, U. \& Boréus, K. (2000). Textens mening och makt. Lund: Studentlitteratur.

Björkdahl, A. (2010). Violence prevention and management in acute psychiatric care: aspects of nursing practice. Stockholm: Karolinska universitetssjukhuset.
Braverman, M. (2002). The prevention of violence affecting workers: a systems perspective. I Gill, M., Fisher, B. \& Bowie, V. (red.) Violence at work: causes, patterns and prevention. Cullompton: Willan. ss. 114-131.

Bowie, V. (2011). An emerging awareness of the role organizational Culture and management style can play in triggering workplace violence. I Privitera, M. (red.) Workplace violence in general health settings. London: Jones and Bartlett publishers. ss. 43-58.

Brännström, L. (2009). Förrättsligande. En studie av rättens risker och möligheter med fokus på patientens ställning. Lund: Bokbox förlag.

Carlsson, N. \& Wennerström, U-B. (2010). Kart läggning och genomlysning av stödet till brottsutsatta personer $i$ Göteborg. Göteborg: Institutionen för socialt arbete/Sociologiska institu- 
tionen, Göteborgs Universitet.

Chappell, D. \& Di Martino, V. (2006). Violence at work. Genève: ILO.

Christie, N. (1999). "Forebyggelse" i Nordisk Tidsskrift for Kriminalvidenskab. ss. 5-15.

Estrada, F., Nilsson, A. \& Wikman, S. (2007). Det ökade våldet i arbetslivet. En analys utifrån de svenska offerundersökningarna. Nordisk Tidsskrift for Kriminalvidenskab. ss. 56-73.

Estrada, F., Nilsson, Jerre, K. och Wikman, S. (2010). Violence at work - the emergence of a social problem. Journal of Scandinavian Studies in Criminology and Crime prevention. ss. 46-65.

EU-OSHA (2011). Occupational safety and health culture assessment - A review of main approaches and selected tools. Luxemburg: Publications office of the European Union.

Geijer, P. \& E. Menckel (2003). Hot och våld i detaljhandeln. Stockholm: Arbetsmiljöverket och Arbetslivsinstitutet.

Giertsen, H. (1994). Forebygging av kriminalitet: altfor bredt og altfor smalt, Nordisk Tidsskrift for Kriminalvidenskab. ss. 295-313.

Goffman, E. (1974). Frame analysis: An essay on the organization of experience. New York: Harper \& Row.

Gustafsson, R. \& Szebehely, M. (2005). Arbetsvillkor och styrning: äldreomsorgens hierarki - en enkätstudie bland personal och politiker. Edsbruk: Akademitryck.

Gray, G. (2009). The responsibilization strategy of health and safety, British Journal of Criminology. ss. 326-342.

Gustafsson, R.(2004). Välfärdstjänsternas ofärd. I Gustafsson, R. \& Lundberg, I. (red) Arbetsliv och hälsa 2004. Stockholm: Arbetslivsinstitutet, Arbetsmiljöverket och Liber Förlag. ss. 257-279.

von Hofer, H. (2006). Ökat våld och/eller vidgade definitioner?, Nordisk Tidskrift for Kriminalvidenskab. ss. 193-208.

Hydén, H. (2004). Hur får vi en bättre arbetsmiljö? Om strategier i arbetsmiljölagstiftningen över tid och vad vi kan lära av det. I Johansson, B., Frick, K. \& Johansson, J. (red.) Framtidens arbetsmiljö - och tillsynsarbete. Lund: Studentlitteratur. ss. 126-151.

Jareborg, N. \& Zila, J. (2007). Straffrättens påföljdslära. Stockholm: Nordstedts Juridik.

Jones, T., A. Robinson, R. Fevre \& D. Lewis (2011). Workplace assaults in Britain. Understanding the influence of individual and workplace characteristics, British Journal of Criminology. ss. 159-178.

Larsson, T. (2004). Förutsättningar för kommunernas arbetsmiljöarbete på 2000-talet. I Johansson, B., Frick, K. \& Johansson, J. (red.) Framtidens arbetsmiljö- och tillsynsarbete. Lund: Studentlitteratur. ss. 184-221.

Larsson, T.J., Normark, M. Oldertz, C. \& Tezic, K. (2011). Allvarliga arbetsskador och långvarig sjukfrånvaro 2011. Stockholm: AFA försäkringar.

Lundberg, L., Hollnagel, E., Rollenhagen, C., \& Rankin, A. (2011). Strategies for dealing with resistance to recommendations from accident investigation. Accident Analysis \& Prevention. ss. $455-467$.

Mathiesen, T. (1985). Rätten $i$ samhället. Göteborg: Bokförlaget Korpen.

Menckel, E. \& Hultin, A. (2004). Arbeten med risk för hot och våld. I Gustavsson, R.A. \& Lundberg, I. (red.) Arbetsliv och hälsa. Stockholm: Arbetslivsinstitutet. ss. 345-361.

Menckel, E. \& Viitasara, E. (2000). Utsatthet för hot och våld $i$ vård och omsorg. En undersökning bland kommunalt anställda. Arbetslivsinstitutet. Stockholm.

Nordin, H. (2000). Förekomst i olika arbetsmiljöer. I Menckel, E. (red.) Hot och våld $i$ vård och omsorg. Fakta forskning och förebyggande arbete. Stockholm: Arbetslivsinstitutet.

Paterson, B., Leadbetter, D., Miller, G. \& Bowie, V. (2009). Re- framing the problem of workplace violence directed towards nurses in mental health services in the UK: A work in progress. International Journal of Social Psychiatry.

Petersson, G. (2005). "Då gick jag in i väggen". Om utbrändhet och arbetsskada som en moralisk kamp. Paper från ACSIS nationella forskarkonferens för kulturstudier, Norrköping. 13-15 juni. 
Rasmussen, J. (2010). Safety in the making. Studies on the discursive construction of risk and safety in the chemical industry. Örebro: Örebro Universitet.

Sahlin, I. (1994). "Stackare" eller" skurk" — om den kluvna klientbilden. Research report 1994:1. Lund: Kriminalvetenskapliga nätverket vid Lunds universitet.

Sahlin, I. (2000). Brottsprevention som begrepp och samhällsfenomen. Lund: Arkiv Förlag.

SOU 2000:3 Välfärd vid vägskäl. Delbetänkande från Kommittén Välfärdsbokslut. Stockholm: Fritzes.

Tham, H. (2002). Brottslingen - vinnare eller förlorare. Flores juris et legum. Festskrift till Nils Jareborg. Uppsala: Iustus förlag. ss. 583-593.

Viitasara, E. (2004). Violence in caring: risk factors, outcomes and support. Stockholm: Arbetslivsinstitutet.

Wikman, S. (2008). Våld på jobbet. Beskrivningar av våld $i$ arbetslivet 1978-2004 i facklig press. Sociologisk Forskning nr 3. ss. 6-31.
Wikman, S., Estrada, F. \& Nilsson, A. (2010). Hot och våld $i$ arbetslivet. En kriminologisk kunskapsöversikt. Rapport 2010:4. Stockholm: Arbetsmiljöverket

Wikman, S. (2011). Hårdare tag på jobbet. Sociologisk Forskning nr 3, ss. 51-73.

Wikman, S. (2012). Våld i arbetslivet. Utveckling, uppmärksamhet och ätgärder. Avhandling. Stockholm: Stockholms universitet, Kriminologiska institutionen.

Åkerström, M. (1993). Våld och hot i sjukvårdsarbeten. Dokumentation av en riksrepresentativ intervjustudie. Lund: Network for Research in Criminology and Deviant Behavior at Lund University.

Åkerström, M. (1997). “Att anmäla våld - en praktik inom lokala kulturer" Nordisk Tidsskrift för Kriminalvidenskab, ss. 125-132.

Åkerström, M. (2002). 'Slaps, punches, pinches but not violence: Boundary-Work in nursing homes for the elderly'. Symbolic Interaction. ss. 515-536.

\section{Summary}

\section{Violence in healthcare Safety measures in occupational injury reports 1987,1997 and 2007}

Workplace violence is a complex occupational hazard that nursing staff face in today's health care environment. This study examines staff-recommended safety measures in the wake of violence and threat-related injuries in occupational injury reports. The results suggest that intervention measures concerning psychosocial factors and structural job aspects such as adequate staffing are far more important than surveillance, staff training and penal sanctions. 